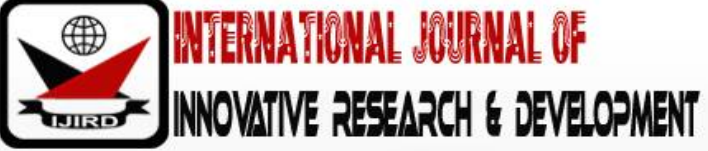

ISSN 2278 - 0211 (Online)

\section{Relationship between KCSE and Preparatory Exam Physics Results in National and Extra County Schools in Makueni County, Kenya}

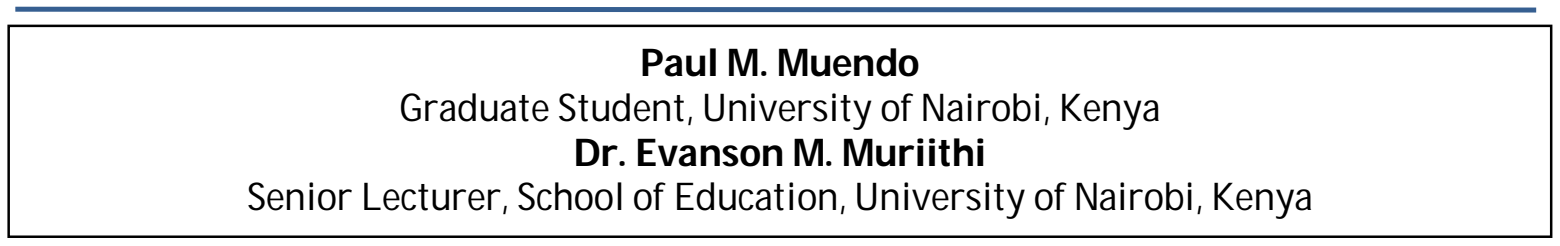

\begin{abstract}
:
Physics is one of the science subjects taught in Kenyan secondary schools in the current 8-4-4 system of education. Students undertake training for a period of four years in the secondary school phase and are examined through the summative examination known as the Kenya Certificate of Secondary Education (KCSE). To ascertain the level of preparedness by the candidates for the final exam, teachers issue a preparatory examination at the end of the second term of the fourth year. This study sought to investigate the relationship between grades obtained by students in Physics in KCSE Exam and preparatory exam. The research was conducted in Makueni County using National and Extra County schools. It was assumed that the preparatory exam was comprehensive and was done in conditions similar to those of the KCSE. The study used Ex Post Facto research design in which physics results from 2016 to 2018 were obtained and analysed. Descriptive statistics were used in checking the objectives whereas inferential statistics was used in testing the hypotheses. From the study, it was observed that students performed better in KCSE examination than in the preparatory examination. However, there was no significant difference in performance in physics between students in National schools and those in Extra County schools in KCSE. It was also found that there was no significant difference in physics performance in preparatory exam in National and in Extra County schools. From the study, preparatory exam lead to good grades in physics in KCSE thus it was recommended that students should be exposed to two or more preparatory examinations so as to improve on the mean score in the final examination. It was further recommended that schools of the same level should do benchmarking of the preparatory examination for this could help bridge the large gap between the grades in preparatory exams and those obtained in KCSE.
\end{abstract}

Keywords: Physics, KCSE, preparatory exam, performance

\section{Introduction}

Physics is the study of matter and its relation to energy and covers a wide range of areas including mechanics, electromagnetism, optics, hydrodynamics and atomic physics (Grayson, 2004). In Kenya secondary schools, physics is taught for four years in the current 8-4-4 system of education. It is tested as an elective science subject in the Kenya Certificate of Secondary Education (KCSE) exam, which is the final exam to mark the end of four years in secondary school. In Ghana, the physics syllabus for senior High School (SHS) is organized to cover three years and students tested for placement in tertiary institutions (Buabeng, Aquinas and Ampiah, 2014). According to Glover, 2018, success in physics opens up various career opportunities to the student. However, at the secondary level of education, it is early to conclude that students will continue learning physics and opt for career in physics (Grayson, 2004).

The world over the past few years has witnessed a vast technological evolvement in almost all spheres of life with physics being the greatest contributor to the growth in technology. According to Johnson(2019) Physics touches every aspect of our lives ranging from modern means of transportation such as the aircraft, telecommunications, internets, smart phones, computers, home technologies such as microwaves, improved medical facilities like radiotherapy, environmental conservation, military application, industrial and commercial application (Grayson, 2004). Johnson (2019) states that many aspects of modern society would not have been possible without physics discoveries made in the past. According to Amadalo (2012) physics enables learners to participate in technologically related studies in institutions of higher learning. Ryan (2013) supports the importance of physics in technology by highlighting the subject as a foundation of each engineering topic and the pedagogical significance to all engineering students.

Despite the magnified and well visible positive impact of physics in society, some learners perceive it to be dull, dry and difficult (Grayson, 2004). Sadi, 2015, conducted a study on the analysis of high school students' conception of learning in difficult domains and found out that students had a negative attitude towards physics. According to Grayson (2004) each discipline within physics is presented in form of laws, rules and principles which are mathematically 
elaborated and this according to Sadi(2015) was the main reason for students having negative attitude towards physics since they could not express physics in mathematical terms. However, in Kenya, the basics of physics are taught in the primary schools in the science subject but most students do not figure out the relationship between sciences they learn in primary and the one taught in secondary school (Murei, 2016). Thus, as learners move from lower to upper classes and advance their studies in science, some see the science classes to be threatening and intimidating to them (Teresa, 2011). Physics according to Ryan(2013) is the most problematic subject within the science domain and most often attracts fewer students. In Kenya, physics is the least preferred and studied science subject (Amadalo, 2012) as seen in the Kenya secondary schools' national enrolment.

\begin{tabular}{|c|c|c|c|c|c|c|c|c|c|}
\hline Subject & $\mathbf{2 0 1 0}$ & $\mathbf{2 0 1 1}$ & $\mathbf{2 0 1 2}$ & $\mathbf{2 0 1 3}$ & $\mathbf{2 0 1 4}$ & $\mathbf{2 0 1 5}$ & $\mathbf{2 0 1 6}$ & $\mathbf{2 0 1 7}$ & Total \\
\hline Math & 357,488 & 41,134 & 436,349 & 446,696 & 483,630 & 520,274 & 570,398 & 609,523 & $2,945,218$ \\
\hline Biology & 317,135 & 363,817 & 389,523 & 397,319 & 432,917 & 465,584 & 509,982 & 545,666 & $2,956,359$ \\
\hline Physics & 109,811 & 120,074 & 119,654 & 119,819 & 131,410 & 139,100 & 149,790 & 160,186 & 910,744 \\
\hline chemistry & 347,364 & 403,070 & 427,386 & 439,847 & 476,582 & 515,888 & 566,836 & 606,518 & $3,267,603$ \\
\hline
\end{tabular}

Table 1: Secondary schools National Enrolment

Source: KNEC Annual Examination Report 2018

From Table 1, the Kenya national enrolment in physics is lower than that of the other science subjects from the year 2010 to 2017. Muli (2012) conducted a research on the factors influencing choice of physics in public secondary schools in Kangundo district in Kenya and found out that students were influenced in their choice of physics through their career goals, poor study habits, their perception of physics as difficult, their gender, poor previous performance and their poor attitude towards the subject. However, Ndegwa(2012) in a research on students' learning challenges in physics in public secondary schools in Kenya found out that students who chose to study physics had a positive attitude towards the subject and that there was higher enrolment in single sex schools than in mixed schools.

To prepare students for the final examination (KCSE), teachers administer an internal preparatory examination to the candidates at the end of the second term in form four and the exam is well prepared to meet the qualities of a standard exam, (Otura, 2015). This exam may at times lack moderation policy since it is set by individual teachers and the marking is done internally (Mufanechiya, 2013). According to Swan(2015) internal assessments are not likely to be comparable across teachers or schools since they may be influenced by local factors in a way that distorts the true assessment of learning outcomes. Kasembeli and Gathara(2014) however noted that an exam prior to KCSE was important since it helped prepare the candidates leading to good results in the final exam. The preparatory exam thus becomes a window through which teachers, parents and students gauge the readiness of the learner to face the final examination. According to Mufanechiya(2013) success in the internal exam was seen as a barometer of the final externally set examination whose inner most purpose is to improve effectiveness in making decisions about people (Adow, Alio and Thinguri, 2015) and in Kenya, the results of the KCSE are used to place students in various courses in the tertiary institutions of learning.

In KCSE exam, physics is tested in 3 papers; paper 1(232/ 1), paper 2(232/2) and paper 3(232/3) (KNEC report 2011). Paper 1 and 2 are theory papers each with 2 sections $A$ and $B$ in which sections $A$ is made of short answer questions and section B structured questions. In paper 1, the learner is tested on mechanics and thermodynamics while in paper 2 , questions are drawn from electricity, magnetism, optics and waves. A candidate is required to answer all the questions in both sections and the maximum score in each paper is 80 marks. The learner's score in paper 1 is added to the score in paper 2 and both are converted to $60 \%$. Paper 3 is a practical exam which tests several skills in physics and has a maximum score of 40 marks. The score in the theory papers is then added to the score in practical paper to get the percentage which in turn is used to generate the final grade and points of the learner. The KCSE results are determined by a 12-point grade system (KNEC, 2018), in which the least grade one can score is $E$ with an equivalent point of 1 while the highest grade is A of 12 points. According to the Kenya National Examinations Council (KNEC), the grading system for 2018 was as follows.

\begin{tabular}{|c|c|c|c|c|c|c|c|c|c|c|c|c|}
\hline $\begin{array}{c}\text { Percentage } \\
\text { (\%) }\end{array}$ & $\begin{array}{c}0 \\
- \\
29\end{array}$ & $\begin{array}{c}30 \\
- \\
34\end{array}$ & $\begin{array}{c}35 \\
- \\
39\end{array}$ & $\begin{array}{c}40 \\
- \\
44\end{array}$ & $\begin{array}{c}45 \\
- \\
49\end{array}$ & $\begin{array}{c}50 \\
- \\
54\end{array}$ & $\begin{array}{c}55 \\
- \\
59\end{array}$ & $\begin{array}{c}60 \\
- \\
64\end{array}$ & $\begin{array}{c}65 \\
- \\
69\end{array}$ & $\begin{array}{c}70 \\
- \\
74\end{array}$ & $\begin{array}{c}75 \\
- \\
79\end{array}$ & $\begin{array}{c}80 \\
- \\
100\end{array}$ \\
\hline Grade & $\mathrm{E}$ & D- & $\mathrm{D}$ & D+ & C- & $\mathrm{C}$ & C+ & B- & B & $\mathrm{B}+$ & A- & A \\
\hline Points & 1 & 2 & 3 & 4 & 5 & 6 & 7 & 8 & 9 & 10 & 11 & 12 \\
\hline
\end{tabular}

A good performance in KCSE enables students to secure places in institutions of higher learning (Musasia, Abacha and Biyoyo, 2012). Swan (2015) states that performance from standardized national exams help stakeholders identify how schools and education systems are performing as measured by student learning outcomes. In Kenya, Mulambe (2017) observed that the national mean score in physics has been low. A similar observation was made in Ghana Senior High schools by Buabeng \& Ampiah (2014) where in their research, they found out that a reasonable percentage of physics content is left uncovered before students sit for the final exam thus the poor results while Marta, Massunaga and Rubini, 2017 on their study in Brazil found out that there were low attainment levels in physics at the end of high school with a small percentage of correct answers. Hence, majority of students were underperforming making access to physicsoriented courses difficult (Murei, 2016). 
Okoth(2018) highlighted inadequate qualified teachers and inappropriate laboratory equipment for teaching physics as the main cause for poor performance in physics, a factor supported by Ndegwa (2012) where she observed that students whose physics lessons were frequently conducted in the laboratory performed better than those students who did not frequent the laboratory. According to Kafata and Mbetwa (2016) lack of guidance to pupils on the importance of the subjects to their higher learning is a factor that contributes to poor performance in sciences. Murei (2016) observed that most students performed well in science in the primary schools but their performance in high school is skewed to the negative.

Student's performance in science is determined by student variables (study habits, attitude and interest towards the subject) but gender does not influence academic performance in sciences (Rashidat and Alake, 2014), a factor supported by Khanyane, Mokuku and Nthathakane (2016) where in their findings, teachers and students had mixed views on which gender performed best. However, Akweya (2015) observed that girls in national schools performed better than boys while Ndegwa, 2010 ascertains that in single sex schools, girls' schools perform better than boys' schools, but a study in Brazil by Marta, Massunaga and Rubini(2017) found out that female students perform worse than male students.

Several studies have shown that students performed poorly in physics questions which had mathematical applications. According to Marta, Massunaga and Rubini (2017), students performed worse in questions that require basic mathematical reasoning a factor supported by Tadele (2016) When he observed that students developed negative attitude on the calculation part of the physics subject while Shekarbaghani (2016) states that it's better to express physics texts with tangible examples and less associated with mathematics as much as possible. However, Vavougious and The odorous(2018) emphasized that the success of teaching and learning is not based on academic excellence, but teaching is successful if students have acquired an ability to criticize, can think creatively and have obtained calculation techniques to understand the operation and structure of the natural world.

\subsection{Purpose}

The main purpose of this study was to compare the relationship between Preparatory and KCSE results in physics in National and Extra county schools in Makueni County in Kenya.

\subsection{Objectives}

- To investigate the relationship between physics grades in preparatory and KCSE exam.

- To investigate the relationship in performance in physics between National and Extra County schools in preparatory exam.

- To investigate the relationship in performance in physics between National and Extra county schools in KCSE.

\subsection{Hypotheses}

- There is no statistically significant difference in performance between KCSE and preparatory grades in physics.

- There is no statistically significant difference in performance between national and extra county schools in preparatory exam.

- There is no statistically significant difference between the performance of national and extra county schools in KCSE exam.

\section{Methodology}

The study used Ex Post Facto research design in which physics results from 2016 to 2018 were obtained and analyzed. Descriptive statistics were used in checking the objectives whereas inferential statistics was used in testing the hypotheses. The t-score for the two sets of mean scores in preparatory and KCSE exams was calculated using the Microsoft Excel Spreadsheet TTEST formula for a two tailed test $=$ TTEST (array1, array2, tails, and type)

Where,

Array1 was the mean score for the preparatory exam while Array2 was the mean score for the KCSE exam, tails indicated it was a two tailed test and it was a two type of t-test since the study was comparing two sets of data. The level of significance used was 0.05 , in which if $\mathrm{p}$ was greater than or equal to 0.05 then the null hypothesis was accepted and if $\mathrm{p}$ value was less than 0.05 , then the null hypothesis was rejected.

\section{Findings and discussions}

\subsection{KCSE and Preparatory Results}

The general mean scores for the schools were as in Table 3 


\begin{tabular}{|c|c|c|c|c|c|}
\hline \multirow{4}{*}{ School } & \multicolumn{2}{|c|}{ Extra County schools } & \multicolumn{2}{c|}{ National schools } \\
\cline { 2 - 6 } & year & W & $\mathbf{X}$ & $\mathbf{Y}$ & $\mathbf{Z}$ \\
\hline Preparatory Exam & 2016 & 2.01 & 7.15 & 4.24 & 5.28 \\
\cline { 2 - 6 } & 2017 & 2.67 & 8.35 & 5.11 & 4.72 \\
\cline { 2 - 6 } & 2018 & 5.03 & 6.52 & 4.79 & 3.92 \\
\hline \multirow{3}{*}{ Kcse Exam } & 2016 & 6.96 & 8.27 & 8.77 & 9.04 \\
\cline { 2 - 6 } & 2017 & 6.19 & 8.44 & 8.05 & 6.48 \\
\cline { 2 - 6 } & 2018 & 5.98 & 6.46 & 8.48 & 0.82 \\
\hline \multicolumn{2}{|c|}{ t- score } & 0.0311 & 0.6683 & 0.000349 & 0.03492 \\
\hline \multicolumn{2}{|c|}{ Level of significance } & 0.05 & 0.05 & 0.05 & 0.05 \\
\hline
\end{tabular}

Table 3: Mean Scores for Both Preparatory and KCSE Exams for the

National and Extra County Schools in Makueni County

From Table 3, physics performance in KCSE exam was better than that of Preparatory exam in three out of the four schools analysed. In the year 2018 for example, students of school W obtain a mean score of 5.03 in preparatory exam and the same students obtained a mean of 5.98 in KCSE exam. On the same year, school Y obtained a mean of 4.79 in preparatory exam and 8.48 in KCSE examination while school Z had a mean of 3.92 in preparatory exam and 6.82 in KCSE exam. This shows that the schools performed better in KCSE exam than in the preparatory exam. However, school X deviated from the rest in the year 2018 where the mean score for preparatory exam was 6.52 while that of KCSE was 6.46. In order to check whether there is any statistical difference in the results, a $t$ - test was conducted to test the null hypothesis.

- H01: There is no statistically significant difference in performance between KCSE and preparatory grades in physics in National and Extra County schools in Makueni County.

From Table 3, the $\mathrm{t}$ - score for school W was 0.0311 , for school X 0.000349 and school Z 0.03492 . Tested on 0.05 level of significance, the $t$ - scores obtained were lower that the $p$ value and thus it is clear that there is a statistical difference between grades in preparatory and KCSE exams. However, the t - score for school X was 0.6683, slightly greater than 0.05 implying there is no statistical difference. To test the hypothesis further, the mean scores for preparatory and KCSE exams were combined for the Extra county, national, and both categories of schools separately and $t$ - score computed. This can be seen from Tables 4,5 and 6.

\begin{tabular}{|c|c|c|c|c|c|}
\hline Year & $\begin{array}{l}\text { Type of Mean } \\
\text { Type of Exam }\end{array}$ & $\begin{array}{c}\text { School } \\
\text { W Initial } \\
\text { Mean }\end{array}$ & $\begin{array}{c}\text { School } \\
\text { X initial } \\
\text { mean }\end{array}$ & $\begin{array}{l}\text { Combined } \\
\text { Preparatory } \\
\text { mean }\end{array}$ & $\begin{array}{c}\text { Combined } \\
\text { KCSE } \\
\text { mean }\end{array}$ \\
\hline \multirow[t]{2}{*}{2018} & Preparatory & 5.03 & 6.52 & 5.94 & \\
\hline & KCSE & 9.98 & 6.46 & & 6.23 \\
\hline \multirow[t]{2}{*}{2017} & Preparatory & 2.67 & 8.35 & 5.09 & \\
\hline & KCSE & 6.19 & 8.44 & & 7.04 \\
\hline \multirow[t]{2}{*}{2016} & Preparatory & 2.01 & 7.15 & 4.21 & \\
\hline & KCSE & 6.96 & 8.27 & & 7.53 \\
\hline & & & & t-score & 0.042 \\
\hline & & & & Sig. & 0.05 \\
\hline
\end{tabular}

Table 4: Combined Preparatory and KCSE Mean for Extra County Schools

From Table 4, the t - score for combined preparatory and KCSE mean scores for extra county schools was obtained to be 0.042 . This value was lower than 0.05 level of significance and thus the null hypothesis was rejected. This implies that there is a statistical difference between grades in preparatory and the KCSE exams for Extra County schools, with the KCSE exams being performed better. 


\begin{tabular}{|c|c|c|c|c|c|}
\hline Year & $\begin{array}{c}\text { Type of } \\
\text { mean }\end{array}$ & $\begin{array}{c}\text { School } \\
\text { Y Initial } \\
\text { Mean }\end{array}$ & $\begin{array}{c}\text { School } \\
\text { Z Initial } \\
\text { Mean }\end{array}$ & $\begin{array}{l}\text { Combined } \\
\text { Preparatory } \\
\text { mean }\end{array}$ & $\begin{array}{l}\text { Combined } \\
\text { KCSE } \\
\text { mean }\end{array}$ \\
\hline & Type of Exam & & & & \\
\hline \multirow[t]{2}{*}{2016} & Preparatory & 4.24 & 5.28 & 4.57 & \\
\hline & KCSE & 8.77 & 9.04 & & 8.86 \\
\hline \multirow[t]{2}{*}{2017} & Preparatory & 5.11 & 4.72 & 4.98 & \\
\hline & KCSE & 8.05 & 6.48 & & 7.52 \\
\hline \multirow[t]{4}{*}{2018} & Preparatory & 4.79 & 3.92 & 4.45 & \\
\hline & KCSE & 8.48 & 6.82 & & 7.84 \\
\hline & & & & $\mathrm{t}$ - score & 0.00135 \\
\hline & & & & Sig. & 0.05 \\
\hline
\end{tabular}

Table 5: Combined Preparatory and KCSE mean for National schools

From Table 5, the t - score of combined preparatory and KCSE mean score for national schools in Makueni County was obtained as 0.00135 , a value lower than 0.05 level of significance thus the null hypothesis for national school was rejected. This shows there is a statistical difference between preparatory and KCSE physics exam results in national schools with the KCSE having been performed better.

\begin{tabular}{|c|c|c|c|c|c|}
\hline \multirow{2}{*}{ Year } & Type of Mean & $\begin{array}{c}\text { Extra } \\
\text { County } \\
\text { Schools }\end{array}$ & $\begin{array}{c}\text { National } \\
\text { Schools }\end{array}$ & $\begin{array}{c}\text { Combined } \\
\text { Preparatory } \\
\text { Mean }\end{array}$ & $\begin{array}{c}\text { Combined } \\
\text { KCSE } \\
\text { Mean }\end{array}$ \\
\hline \multirow{2}{*}{2018} & Type of Exam & 5.94 & 4.45 & 4.88 & \\
\hline \multirow{2}{*}{2017} & Preparatory & 6.23 & 7.84 & & 7.37 \\
\hline \multirow{2}{*}{2016} & KCSE & 5.09 & 4.98 & 5.01 & 7.36 \\
\cline { 2 - 6 } & Preparatory & 7.04 & 7.52 & & 8.33 \\
\cline { 2 - 5 } & KCSE & 4.21 & 4.57 & 4.43 & 0.00136 \\
\hline & KCSE & 7.53 & 8.86 & t- score & 0.05 \\
\hline
\end{tabular}

Table 6: Combined Preparatory And KCSE Mean For both National and Extra County Schools

When both scores for national and extra county schools were combined and t score computed, it was obtained to be 0.00136 as shown in Table 6 . This value was lower than 0.05 level of significance and thus the null hypothesis that there is no statisticallysignificantdifference between physics grades in preparatory and KCSE exam was rejectedand the alternative was accepted that there is a statistical difference between preparatory and KCSE results. The schools performed better in KCSE exam than preparatory exam. Kasembeli and Gathara (2014) conducted a similar research were 5 out of 6 selected schools performed better in KCSE than preparatory exam which in their case they called partnership exam. According to Mufanechi(2013) these preparatory exams were useful in finding out the learner's strength and difficulties and helped teachers improve those areas to enable the learner perform better in the final exam. However, although the preparatory exam is set and done in similar condition as the KCSE, it should not be used as a bench mark for KCSE (Otura, 2015) since students performed way better in KCSE.

\subsection{Preparatory Exam Results for National and Extra County Schools}

Each school sets its own preparatory exam to prepare students for KCSE. From Table 2, the mean scores for both Extra County and National Schools in physics in preparatory exam were almost similar with neither category performing better than the other. In the year 2017 for example, schools W and X which are County schools had mean scores of 2.67 and 8.35 respectively in preparatory exam while schools $\mathrm{Y}$ and $\mathrm{Z}$ which are National schools had mean scores of 5.11 and 4.72 respectively. The two national schools performed better than school W but school X performed better than the National schools. To test whether there is any statistical difference between the scores, the null hypothesis was tested.

- H02: There is no statistically significant difference in performance between national and extra county schools in preparatory exam in Makueni County.

The mean score for preparatory exam was obtained to generate Table 7. The t score was calculated and tested at $95 \%$ level of confidence. 


\begin{tabular}{|c|c|c|}
\hline School Type & $\begin{array}{c}\text { Extra County } \\
\text { Schools }\end{array}$ & $\begin{array}{c}\text { National } \\
\text { Schools }\end{array}$ \\
\hline 2016 & 4.21 & 4.43 \\
\hline 2017 & 5.09 & 5.01 \\
\hline 2018 & 5.94 & 4.88 \\
\hline & t - score & 0.593 \\
\hline & Sig. level & 0.05 \\
\hline
\end{tabular}

Table 7: Combined Mean Score for Preparatory Exams for Both

National and Extra County Schools in Makueni County

From Table seven, the $t$ - score was found to be 0.593 , a value above the p value of 0.05 . Thus, the null hypothesis was accepted meaning there is no statistically significant difference between the performance in physics of National and Extra County schools. Although the grades in preparatory exam were lower than those for KCSE Exam, they were low for both categories of schools and no category performed better than the other. A teacher in one of the schools admitted that their preparatory exams are abit tough than the KCSE exam so as to enable students harden up for the final exam.

\subsection{KCSE results for National and Extra county schools.}

From Table 3, both categories of schools had similar mean scores in KCSE exam with no category performing exceedingly better than the other. For example, in the year 2017, the county schools W and X had KCSE mean scores of 6.19 and 8.44 respectively while national schools $\mathrm{Y}$ and $\mathrm{Z}$ had mean score of 8.05 and 6.48 respectively. To test whether there is any statistical difference between the results, a t - test was carried out to test the null hypothesis:

- H03: There is no statistically significant difference between the performance of National and Extra county schools in physics in KCSE exam in Makueni County. results

The KCSE results in physics for the two categories of schools were analyzed and $t$ - test performed on the obtained

\begin{tabular}{|c|c|c|}
\hline School Type & $\begin{array}{c}\text { Extra County } \\
\text { Schools }\end{array}$ & $\begin{array}{c}\text { National } \\
\text { Schools }\end{array}$ \\
\hline Year & 7.53 & 7.84 \\
\hline $\mathbf{2 0 1 6}$ & 7.04 & 7.52 \\
\hline $\mathbf{2 0 1 7}$ & 6.23 & 8.86 \\
\hline $\mathbf{2 0 1 8}$ & t - score & $\mathbf{0 . 1 0 9}$ \\
\hline & Sig. & 0.05 \\
\hline
\end{tabular}

Table 8: Combined Mean Score for KCSE Examination for Both

National and Extra County Schools in Makueni County

The $\mathrm{t}$ - score was obtained as 0.109 , a value higher than the $\mathrm{p}$ value of 0.05 and the null hypothesis was accepted. Thus, there is no statistically significant difference between the performance of national and extra county schools in physics in KCSE exam. This means schools in both categories performed well in KCSE examinations, since it is the final examination done after the completion of the course (Renard, 2017). According to Musasia, Abacha and Biyoyo(2012) a good performance in the final exam enables students to secure places in institutions of higher learning.

\section{Conclusion}

The study found out that students performed better in physics in KCSE exams than in Preparatory exams, since there was a significant difference between the results obtained. It thus implies that the preparatory exams helped prepare students for the final exam. The fact that the exams are done three months before the KCSE and that they are a true reflection of the syllabus (Otura, 2015) means that students and teachers had room to improve on the weak areas in readiness for the KCSE. However, Mulambe (2017) observed that the national mean score in physics has been low.

\section{Recommendations}

The following recommendations can be made from the findings and conclusions.

- Students should be allowed to sit for two or more preparatory exams so that the national mean score of physics improves.

- The preparatory exams can be benchmarked within schools of the same level to investigate if the grades from these exams can match the grades in KCSE.

- Further research can be done to determine the factors which lead to low grades in preparatory exams compared to the grades obtained in KCSE examination. 


\section{References}

i. Adow I, Alio A and Thinguri R. (2015). An assessment of the management of KCSE Examination and its influence on irregularities among students: A case study of secondary schools in Mandera County, Kenya. Journal of Education and Practice Vol. 6, No. 28

ii. Agbaje, Rashidat O, \&Alake, (2014). Students' Variables as Predictor of Secondary School Students' Academic Achievement in Science Subjects. International Journal of Scientific and Research Publications, Volume 4, Issue 9 available on http:/ / www.ijsrp.org/ research-paper-0914/ ijsrp-p3375.pdf

iii. Akweya J, Twoli N, Waweru G. (2015). Factors influencing Girls performance in Physics in national schools in Kiambu and Nairobi counties of Kenya. International journal of secondary Education Vol 3, No 4.

iv. Amadalo M. M, Ocholla A. A, Memba E. B, (2012) Effects of practical work in physics on Girls performance, attitude change and skills acquisition in the form two - form three secondary schools transition in Kenya. International journal of humanities and social sciences Vol.2 No. 23

v. Babalola F. (2017). Advancing practical physics in Africa's schools available on http:/ / oro.open.ac.uk/ 50740/

vi. Briones C.B (2018). Teachers' Competency on the Use of ICT in Teaching Physics in the Junior High School. https:/ / knepublishing.com/ index.php/ Kne-Social/article/ view/ 2380/ 5240

vii. Buabeng, Aquinas and Ampiah (2014). An investigation into physics in senior high schools. World journal of education vol. 4 no. 5. https:/ / files.eric.ed.gov/ fulltext/ EJ1158569.pdf

viii. Glover D. (2018). Secondary Physics form one students' Book, Kenya: Moran publishers

ix. Grayson D. (2004). Introduction to "What physics should we teach", International Conference on Physics Education $\quad$ conference $\quad$ 10.13140/2.1.2636.8002. Available on https:/ / www.researchgate.net/ publication/ 267390929 Introduction_to_What_physics_should_we teach_Internat ional Conference on Physics Education conference 2004

x. Hales J. (2018). The $\overline{3}$ basic types of descriptive research methods' available on https// psychcentral.com/ blog/the3-basic-types-of-descriptive-research-methods/

xi. Hanne, Anderson and Cozart (2014). Assessment Methods and practices in higher Education in Denmark. https:/ / dun-net.dk/ media/ 120513/ assessment-methods-and-practices-andersen-cozart-2014.pdf

xii. Johnson S. (2018). The Roles of Physics in Our Modern Society. https:/ / sciencing.com/ the-roles-of-physics-in-ourmodern-society-12746626.html

xiii. Kafata F. \& Mbetwa S., 2016 An investigation into the failure rate in mathematics and science at Grade 12 examinations and its impact to the school of engineering: A case study of Kitwe District of Zambian. International journal of scientific and technology research Vol. 5 available on http:// www.ijstr.org/ final-print/ aug2016/ AnInvestigation-Into-The-Failure-Rate-In-Mathematics-And-Science-At-Grade-Twelve-12-Examinations-And-ItsImpact-To-The-School-Of-Engineering-A-Case-Studyof-Kitwe-District-Of-Zambia.pdf

xiv. Kasembeli D. And Gathara P.M, (2014). Partnership in secondary school assessment examinations and Kenya certificate of secondary Education Examination. https:/ / ir-library.ku.ac.ke/ handle/ 123456789/ 11621 ?show=full

xv. Kenya National Examination Council (2018). Available at http:// knecportal.co/knec-kcse-gradingsystem-2018-inkenya.

xvi. Khanyane, Marethabile, Mokuku, Nthathakane, Malefu C. (2016). Perceived Gender Differences in Performance in Science: The Case of Lesotho Secondary Schools. African Journal of Research in Mathematics, Science and Technology Education, v20 n3 p278.

xvii. Mart F.B, Massunaga M.S.O \& Rubini. (2017). Brazilian National High School Examination: assessing student's learning in Physics. https:/ / arxiv.org/ abs/ 1707.04181

xviii. Mufanechiya A. (2013). The relevance of Internal and External Examinations in Zimbabwean secondary schools: The Quality Dilemma. Greener Journal of Educational Research.3.326-331.10.15580/ GJER.2013.7.172313743

xix. Mulambe S.O (2017). School factors influencing the adoption of physics SMASSE teaching skills by physics Teachers in secondary schools in Kenya. American Scientific Research Journal for Engineering, Vol 35, No. 1

xx. Muli P. (2012). Factors Influencing Choice of Physics in Public secondary Schools in Kangundo District, Machakos County, Kenya. Available at

https:/ / irlibrary.ku.ac.ke/ bitstream/ handle/ 123456789/ 5483/ Muli\%20Penninah\%20Mbithe.pdf?sequence=3

xxi. Munishi O., Muni E., Omolo H \&Mwangasha G. (2016). Secondary physics students book one (fourth edition), Kenya: Published by Kenya literature Bureau.

xxii. Murei G. Kiptum (2016). Impacts of low enrolment in secondary schools' physics to attainment of Kenya vision 2030: A case study of Nandi North sub - county. International research journals available online at http:/ / www.interesjournals.org/ ER

xxiii. Ndegwa F.N (2012). Student's learning challenges in physics in public secondary schools in Laikipia County, Kenya. Available

https:/ / irlibrary.ku.ac.ke/ bitstream/ handle/ 123456789/ 18896/ Students\%27\%20learning\%20challenges....pdf? sequence=1\&isAllowed=y

xxiv. Otura E. O. (2015). The role of mock examination in predicting performance in Kenya National Examination results. A case of secondary schools in Migori County, Kenya. Available at https://irlibrary.ku.ac.ke/ handle/ 123456789/ 13496

xxv. Ryan M. G. (2013). Attitude and Motivation towards Learning Physics. International Journal of Engineering Research and Technology. 2 2087.2094 
xxvi. Sadi O. (2015). The analysis of high school student's conception of learning in different domains. International journal of environment and science education Vol 10. available on https:/ / files.eric.ed.gov/ fulltext/ EJ1082066.pdf

xxvii. Swan A., 2015 "what are exams good for? Primary and secondary school exam reforms in Papua New Guinea (PNG) available on http:/ / www.devpolicy.org/ what-are-exams-good-for-primary-and-secondary-school-examreform-in-png-20151215/

xxviii. Tadele K (2016). Student's attitudes towards physics in primary and secondary schools of Dire Dawa City administration, Ethiopia. https:/ / www.researchgate.net/ publication/ 299340677

xxix. Teresa L. (2011). Assessment of student understanding in physics: An integrated Qualitative and Quantitative approach. American University Washington D.C

xxx. The Kenya National Examinations Council, 2018. The year 2017 KCSE Examination Report Mathematics and sciences. Vol2.

xxxi. Vavougious D and Theodorous E. K (2008). Application of ICT technology in Physics Education: teaching and learning elementary oscillations with the aid of simulation software. International journal of Emerging Technologies in Learning 